\title{
Study of Zirconium and Hafnium Separation by Solvent Extraction Technique from Nitric and Hydrochloric Solutions with Acid, Basic and Neutral Extractants
}

\author{
Janúbia Cristina B. S. Amaral, Carlos Antônio de Morais \\ Centro de Desenvolvimento da Tecnologia Nuclear (CDTN), Belo Horizonte, Brazil \\ Email: jcbsa@cdtn.br, cmorais@cdtn.br
}

How to cite this paper: Amaral, J.C.B.S. and de Morais, C.A. (2016) Study of Zirconium and Hafnium Separation by Solvent Extraction Technique from Nitric and Hydrochloric Solutions with Acid, Basic and Neutral Extractants. World Journal of Engineering and Technology, 4, 138-150.

http://dx.doi.org/10.4236/wjet.2016.43D017

Received: September 2, 2016 Accepted: October 13, 2016

Published: October 20, 2016

\begin{abstract}
This paper describes the study of the extraction of $\mathrm{Zr}$ and $\mathrm{Hf}$ in nitric and hydrochloric media by solvent extraction technique using different types of extractants. The effect of the extractants DEHPA, IONQUEST ${ }^{\oplus} 801$ and CYANEX ${ }^{\oplus} 272$, TBP, CYANEX ${ }^{\oplus}$ 923, PRIMENE JTM, ALAMINE 336 and ALIQUAT ${ }^{\oplus} 336$ was investigated. For acid extractants in both nitric and hydrochloric media, a high degree of extraction was observed, although they had low selectivity in separating the metals. For the acid extractants also, it was not possible to strip the metals from the organic phase through acid solutions. In this case, a stripping solution with very high acidity would be required, and this is not viable. When the basic extractants were used, no metal extraction was observed under the conditions investigated, indicating no extractable anionic species in either media. The optimum zirconium/hafnium separation was achieved using an acidity of $7.0 \mathrm{~mol} \cdot \mathrm{L}^{-1}$, nitrate concentration of $9.2 \mathrm{~mol} \cdot \mathrm{L}^{-1}$ and $1.5 \mathrm{~mol} \cdot \mathrm{L}^{-1}$ of TBP. In these conditions, a separation factor of 12.6 was obtained.
\end{abstract}

\section{Keywords}

Zirconium, Hafnium, Zircon, Solvent Extraction

\section{Introduction}

Zirconium ( $\mathrm{Zr}$ ) is an element with a wide range of applications in modern technology. Among the applications of zirconium alloys, the use in nuclear area to coat the structural materials is highlighted due to its low thermal neutrons capture cross section, approximately $1.9 \times 10^{-29} \mathrm{~m}^{2}$ [1] [2]. The main economic source of zirconium, its com- 
pounds and alloys is Zirconium Silicate $\left(\mathrm{ZrSiO}_{4}\right)$ known as Zircon. It is the most abundantzirconium mineral and it has great commercial importance. Due to the similarity of their chemical and physical properties, hafnium (Hf) is commonly found in nature associated with zirconium minerals. It is mainly used in alloys with nickel for the production of superalloys and as thermal neutron absorber in power reactors, due to its high thermal neutrons capture cross section, around $1.04 \times 10^{-26} \mathrm{~m}^{2}$-about a thousand times higher than that of zirconium $\left(1.9 \times 10^{-29} \mathrm{~m}^{2}\right)$ [1]-[3]. Among the features of these elements, it can be highlighted the fact that unlike $\mathrm{Zr}$, Hf is a good neutron absorber. Thus for the application of concentrated $\mathrm{Zr}$ in nuclear reactors, it is necessary that it present levels of less than $100 \mathrm{mg} \cdot \mathrm{kg}^{-1}$ of $\mathrm{Hf}$ [4]. Therefore the separation of these elements is of utmost importance for the use of zirconium tubes containing nuclear fuel. However, due to the great chemical similarity between $\mathrm{Zr}$ and $\mathrm{Hf}$ their separation is difficult [2] [5] [6]. Thus, the separation of zirconium and hafnium require elaborate processes. Among the known commercial processes, four are used industrially: fractional crystallization, solvent extraction, distillation of chloride and ion exchange [7][12]. The present work evaluated, through the technique of solvent extraction, the behavior of different types of extractants in two nitric and hydrochloric media in order to obtain a better extraction of zirconium and a greater selectivity between zirconium and hafnium. Acid extractants such as di-2-ethylhexyl phosphoric acid (DEHPA), 2-ethylhexyl phosphonic acid mono-2-ethylhexyl ester (IONQUEST ${ }^{\circ}$ 01), and bis (2,2,4-trimethyl-pentyl)phosphinic acid(CYANEX'272), solvating extractants such as tributyl phosphate (TBP), mixtures of alkylphosphinesoxides (CYANEX 923) and basic extractants such as a primary amine (PRIMENE JMT), a tertiary amine (ALAMINE 336 ) and a quaternary ammonium salt (ALIQUAT 336$)$ [13]-[15].

\section{Theory}

The extraction and separation behavior of zirconium and hafnium has been widely studied. There are several reports on the separation of these elements in different media and extractants. Figure 1 shows the structure of the extractants used in this work for the extraction of the zirconium and hafnium [16].

\section{Experimental}

\subsection{Feed Solutions}

The feed solutions used were prepared from the liquors obtained from the solubilization of zirconium $\left(\mathrm{Zr}(\mathrm{OH})_{4}\right)$ and hafnium $\left(\mathrm{Hf}(\mathrm{OH})_{4}\right)$ hydroxides, both provided by Centro Tecnológico da Marinha-São Paulo (CTM)-SP. The product of the alkaline fusion of zircon was also used. The solubilization of $\mathrm{Zr}$ and $\mathrm{Hf}$ hydroxides was carried out with hydrochloric and nitric acids. The solution using the fusion product of zircon was prepared with nitric acid. The $\mathrm{pH}$ of the solution was adjusted by adding nitric acid or hydrochloric acid, according to the medium and acidity of the experiment. The chemical characterization of the liquors used in the solvent extraction experiments is presented in Table 1. 


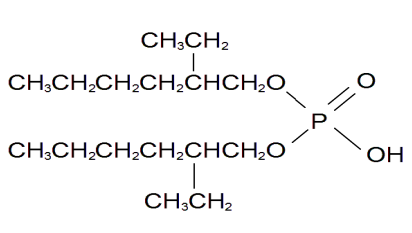

DEHPA

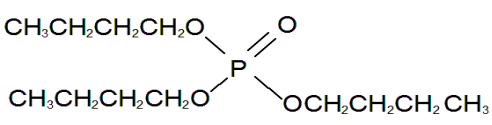

TBP

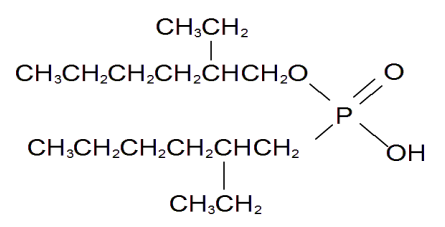

IONQUEST $^{\circledR} 801$

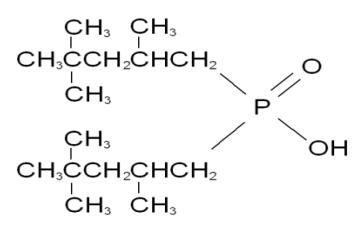

CYANEX $^{\circledR} 272$
$\mathrm{R}_{3} \mathrm{~N}$
Where $\mathrm{R}=\left[\mathrm{CH}_{3}\left(\mathrm{CH}_{2}\right)_{7}\right]-$
$\left[\left(\mathrm{CH}_{3} \mathrm{CH}_{2}\right)_{7}\right]_{3} \mathrm{~N}^{+} \mathrm{CH}_{3} \mathrm{Cl}^{-}$

ALAMINE ${ }^{\circledR} 336 \quad$ ALIQUAT $^{\circledR} 336$

Figure 1. Structural formula of the extractants used in this work.

Table 1. Chemical characterization of $\mathrm{Zr}$ and $\mathrm{Hf}$ liquors used in the solvent extraction experiments.

\begin{tabular}{cccccccccc}
\hline \multirow{2}{*}{ Sample } & \multicolumn{7}{c}{ Species $\left(\mathrm{g} \cdot \mathrm{L}^{-1}\right)$} \\
\cline { 2 - 8 } & $\mathrm{Zr}^{4+}$ & $\mathrm{Hf}^{4+}$ & $\mathrm{NO}_{3}^{-}$ & $\mathrm{Cl}^{-}$ & $\mathrm{SO}_{4}^{2-}$ & $\mathrm{Fe}^{3+}$ & $\mathrm{Ti}^{4+}$ & $\mathrm{Si}^{4+}$ \\
\hline Solution-Nitric médium & $\mathrm{a}$ & 15.0 & 0.6 & $\mathrm{~b}$ & - & 2.4 & 0.03 & $<0.01$ & 2.3 \\
Solution-Hydrochloric médium $^{\mathrm{a}}$ & 15.0 & 0.6 & - & $\mathrm{b}$ & 1.7 & 0.02 & $<0.01$ & 1.3 \\
Zr-Hf Zirconite-Nitric medium $^{2}$ & 20.5 & 0.4 & $\mathrm{~b}$ & - & 0.8 & 0.6 & 0.2 & 2.8 \\
\hline
\end{tabular}

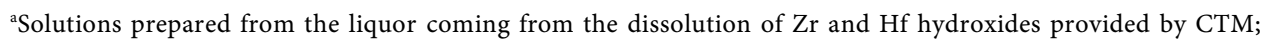
${ }^{\mathrm{b}}$ The $\left[\mathrm{NO}_{3}^{-}\right]$and $\left[\mathrm{Cl}^{-1}\right]$ varied according to experiment.

\subsection{Extractant Agents}

The extractant agents used in this study were: DEHPA and IONQUEST 801 manufactured by Albright and Wilson Americas and supplied by Pecos Brazil Ltda.; CYANEX 272 manufactured by Albright and Wilson Americas and supplied by Cytec of Brazil Ltda.; TBP manufactured by Riedel-de Haen (Hannover, Germany); CYANEX 923 by Cytec Canada-INC; PRIMENE JMT (primary amine) provided by Hohm and Haas Company; Alamine 336 (tertiary amine) and Aliquat 336 (quaternary ammonium salt) supplied by Cognis of Brazil Ltda. The extractant solutions were prepared at specified concentrations by dilutingthem in dodecane, and tridecanol 5.0\% volwas added to the amine solutions.

\subsection{Solvent Extraction Procedure}

The solvent extraction experiments were performed in a $150 \mathrm{ml}$ beaker at temperature 
of about $25^{\circ} \mathrm{C}$ with equal volumes of aqueous and organic phases. The contact between the phases was carried out through mechanical agitation using IKA agitators model RW $20 . \mathrm{n}$ at $350 \mathrm{rpm}$. The agitation time was 15 minutes. After contact, the aqueous/organic mixture was transferred to a separation funnel where the phases were separated and sent for analysis. The $\mathrm{Zr}$ and $\mathrm{Hf}$ were determined by Energy Dispersive X-ray Fluorescence Spectrometry-EDXRF (Shimadzu-EDX 720). The nitrate was determined through molecular absorption spectrophotometry in the ultraviolet region $(302 \mathrm{~nm})$ using a UV-visible spectrophotometer (Varian-Cary 50 conc). The acidity of the aqueous phase was determined by potentiometry using a $\mathrm{pH}$ meter (Digimed-DM 22).

The study of the effect of the acidity on the extraction of $\mathrm{Zr}$ and $\mathrm{Hf}$ for different classes of extractants was performed. The tests were conducted with feed solutions containing fixed concentrations of $\mathrm{Zr}$ and $\mathrm{Hf}$ and varying the acidity of the solution. The concentrations of the metals $\mathrm{Zr}$ and $\mathrm{Hf}$ in the aqueous phase in both hydrochloric and nitric medium were $15 \mathrm{~g} \cdot \mathrm{L}^{-1}$ and $0.6 \mathrm{~g} \cdot \mathrm{L}^{-1}$ respectively. In the experiments with acid extractants, the acidity of the aqueous phase was varied from 1.0 to $5.0 \mathrm{~mol} \cdot \mathrm{L}^{-1}$ of $\mathrm{H}^{+}$, while the nitrate concentration was between 1.3 and $4.9 \mathrm{~mol} \cdot \mathrm{L}^{-1}$. The chloride concentration was varied from 1.1 to $5.7 \mathrm{~mol} \cdot \mathrm{L}^{-1}$, increasing with acidity. In the experiments with solvating extractants and basic extractants, the acidity varied from 1.0 to 10.0 $\mathrm{mol} \cdot \mathrm{L}^{-1}$, the concentration of nitrate varied from 1.3 to $11 \mathrm{~mol} \cdot \mathrm{L}^{-1}$ and the chloride concentration varied between 1.1 and $10.8 \mathrm{~mol} \cdot \mathrm{L}^{-1}$, increasing with acidity. The concentration of the extractants used in organic phase was $1.5 \mathrm{~mol} \cdot \mathrm{L}^{-1}$ for acid and solvating extractants and $0.5 \mathrm{~mol} \cdot \mathrm{L}^{-1}$ for amines.

The study of the effect of the type of feed solution on the extraction of $\mathrm{Zr}$ and $\mathrm{Hf}$ for chosen extractant was performed. The tests were conducted with feed solutions generated from the leaching product of alkaline fusion of zircon and of the solution generated from the hydroxides of $\mathrm{Zr}$ and $\mathrm{Hf}$ in a nitric acid medium. The concentration of the metals $\mathrm{Zr}$ and $\mathrm{Hf}$ in the both aqueous phase were 15.0 and $0.6 \mathrm{~mol} \cdot \mathrm{L}^{-1}$, respectively, and the acidity of the aqueous phase was variedfrom 1.0 to $7.0 \mathrm{~mol} \cdot \mathrm{L}^{-1}$. The nitric concentration increased with acidity, and varied from 3.5 to $9.2 \mathrm{~mol} \cdot \mathrm{L}^{-1}$ for zircon liquor and from 1.41 to $7.5 \mathrm{~mol} \cdot \mathrm{L}^{-1}$ for hydroxides liquor.

\section{Results and Discussion}

\subsection{Acid Extractants}

Studies of the complexation of zirconium by chloride and nitric ions have indicated the presence of the $\mathrm{Zr}$ (IV) cation which can be extracted by acidic extractants. In the literature two kinds of $\operatorname{Zr}(\mathrm{IV})$ cations in the aqueous solution of the acids concentrates have been reported to exist, $\mathrm{ZrO}^{2+}$ and $\mathrm{Zr}^{4+}$. Acid extractants are used in systems where the metals are present in the solubilized form of their cation [4]. The acid extractants form complexes by replacing protons of the molecule with the metal ions present in the aqueous medium, thus extracting the metal by cation exchange mechanism [17]. In this case, the $\mathrm{H}^{+}$of the acid extractant is replaced by the metal cation, as shown in the Equation (1). 


$$
\mathrm{M}^{\mathrm{n}+}+\mathrm{nHA} \rightleftarrows \mathrm{MA}_{\mathrm{n}}+\mathrm{nH}^{+}
$$

1) Nitric medium

Figure 2 shows the results of the extraction of zirconium and hafnium using the acid extractants DEHPA, IONQUEST ${ }^{\circ} 801$ and CYANEX 272 in a nitric medium. Table 2 shows the separation factor of $\mathrm{Zr} / \mathrm{Hf}$ for the acid extractants in this medium. All acid extractants investigated showed a high performance in the extraction for all acidities; however, the selectivity was not satisfactory. The best separation factors were obtained for CYANEX 272 , but with high Hf extraction-more than $90 \%$. The high percentage of extraction obtained indicates the difficulty to strip metals from the organic phase. This fact combined with low separation factor lead to the conclusion that this class of extractant is not the most suitable for the separation of $\mathrm{Zr} / \mathrm{Hf}$ metals.

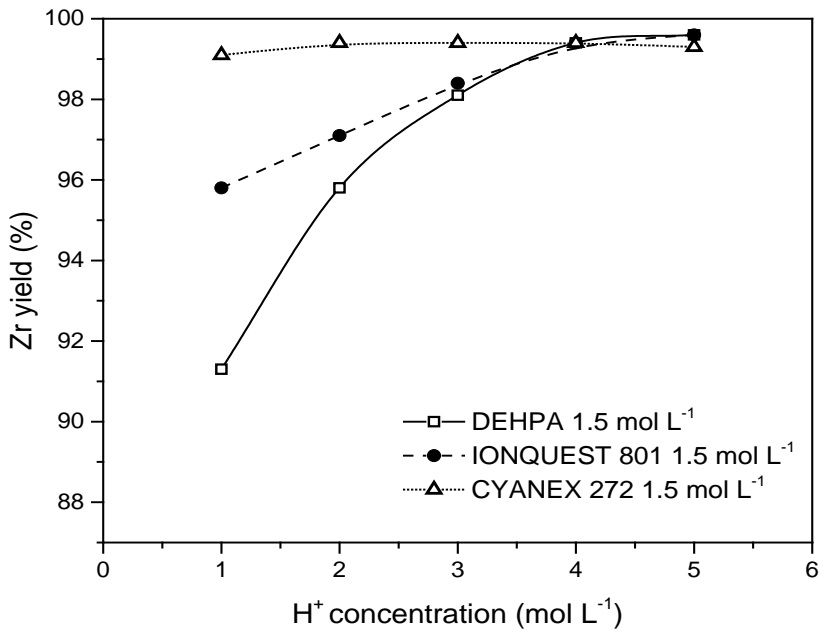

(a)

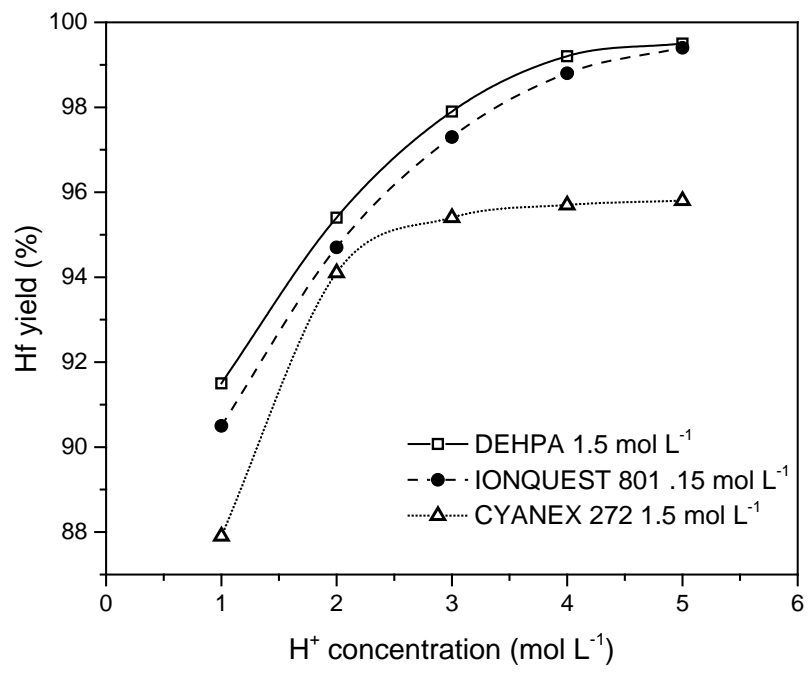

(b)

Figure 2. Efficiency in the extraction of $\mathrm{Zr}(\mathrm{a})$ and $\mathrm{Hf}(\mathrm{b})$ for the acid extractants in nitric medium. Aqueous phase: $15.0 \mathrm{~g} \cdot \mathrm{L}^{-1}$ of $\mathrm{Zr}, 0.6 \mathrm{~g} \cdot \mathrm{L}^{-1}$ of $\mathrm{Hf}, 1.0$ to $5.0 \mathrm{~mol} \cdot \mathrm{L}^{-1}$ of $\mathrm{H}^{+}, 1.3$ to $4.9 \mathrm{~mol} \cdot \mathrm{L}^{-1}$ of $\mathrm{NO}^{3-}$ and $25^{\circ} \mathrm{C}( \pm 2)$. 
Table 2. Separation factor of the $\mathrm{Zr} / \mathrm{Hf}$ for the acid extractants in nitric medium.

\begin{tabular}{cccc}
\hline \multirow{2}{*}{$\mathrm{H}^{+}\left(\mathrm{mol}^{-1} \mathrm{~L}^{-1}\right)$} & \multicolumn{3}{c}{ Separation factor $(\mathrm{SF}) \mathrm{Zr} / \mathrm{Hf}$} \\
\cline { 2 - 4 } & DEHPA & IONQUEST $^{\infty} 801$ & CYANEX $272^{\circ} 22.9$ \\
\hline 1.0 & 1.0 & 1.4 & 26.4 \\
2.0 & 1.1 & 1.2 & 23.6 \\
3.0 & 1.1 & 1.6 & 25.3 \\
5.0 & 1.3 & 1.9 & 25.1 \\
\hline
\end{tabular}

2) Hydrochloric medium

Figure 3 shows the results of the extraction of zirconium and hafnium using the acid extractants DEHPA, IONQUEST 801 and CYANEX 272 in a hydrochloric medium. Table 3 shows the separation factor of $\mathrm{Zr} / \mathrm{Hf}$ for the acid extractants in this medium. The behavior of the acid extractants in a hydrochloric medium was very similar to that in a nitric medium, obtaining a high extraction yield for all acidities investigated, but without good selectivity. The best separation factors were obtained for CYANEX 272 , but with high extraction of Hf. The separation factor in this case occurs mainly due to the difference in the concentrations of the metals in the aqueous phase; however, it does not indicate a condition of separation of metals.

\subsection{Basic Extractants-Nitric and Hydrochloric Medium}

The experiments were conducted using the basic extractants PRIMENE'JMT, ALAMINE 336 and ALIQUAT 336 . The basic extractantsare usually used at lower concentrations than those used for acid or solvating extractants. In these experiments, the concentration of the extractants was $0.5 \mathrm{~mol} \cdot \mathrm{L}^{-1}$.

Under the conditions of the experiments, none of the basic extractants investigated showed any efficiency in the extraction of $\mathrm{Zr}$ and $\mathrm{Hf}$ metals in either media. This class of extractants extracted neutral or anionic species. According to literature [18], the formation of anionic complexes with $\mathrm{Zr}$ occurs at high acidities, above $1.0 \mathrm{~mol} \cdot \mathrm{L}^{-1}$, however, it is also known that amines are generally employed as extractants in less acidic solutions-pH close to 1 or higher. This may be the essential factor for no metal being extracted by amines [19].

\subsection{Solvating Extractants}

1) Nitric medium

Figure 4 shows the results of the extraction of zirconium and hafnium using the acid extractants TBP, CYANEX 923 and TBP/CYANEX 923 in a nitric medium. Table 4 shows the separation factor of $\mathrm{Zr} / \mathrm{Hf}$ for the solvating extractants for this medium. For solvating extractants, the percentage of metal extraction and the separation factor increases as the acidity rises. For CYANEX 923 , the extraction yield of the metals in low acidity is higher when compared to TBP. In acidity greater than $3.0 \mathrm{~mol} \cdot \mathrm{L}^{-1}$ the 


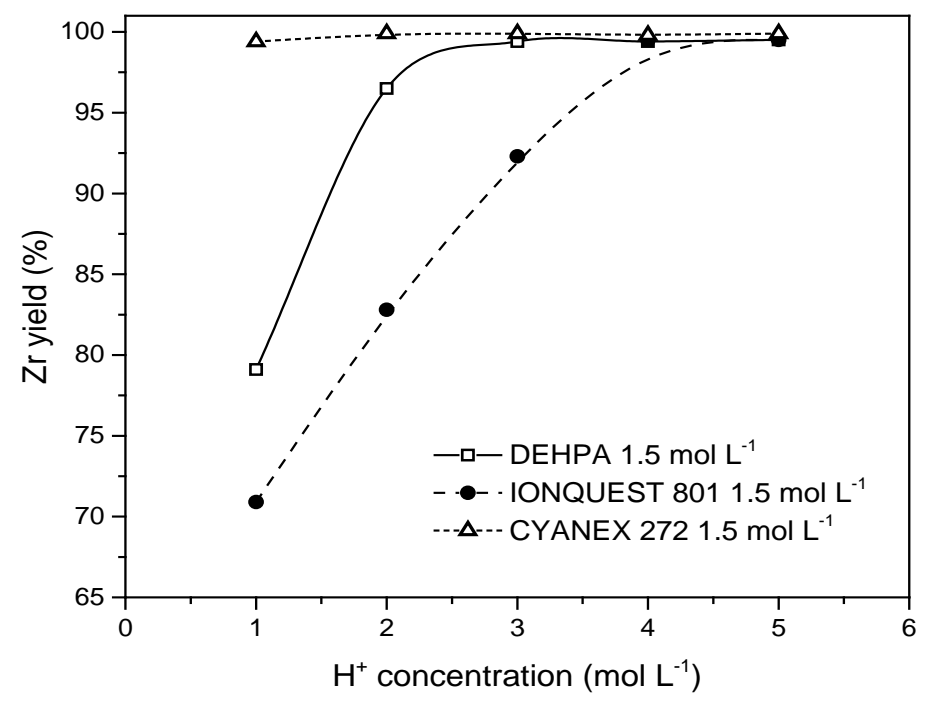

(a)

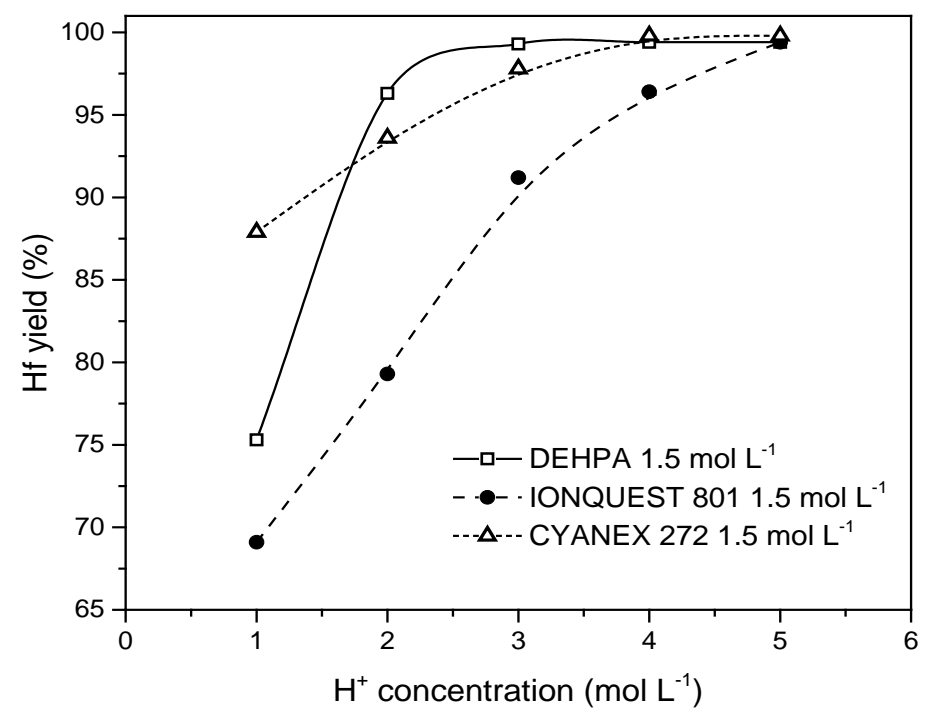

(b)

Figure 3. Efficiency in the extraction of $\mathrm{Zr}$ (a) and $\mathrm{Hf}(\mathrm{b})$ for the acid extractants in hydrochloric medium. Aqueous phase: $15.0 \mathrm{~g} \cdot \mathrm{L}^{-1}$ of $\mathrm{Zr}, 0.6 \mathrm{~g} \cdot \mathrm{L}^{-1}$ of $\mathrm{Hf}, 1.0$ to $5.0 \mathrm{~mol} \cdot \mathrm{L}^{-1}$ of $\mathrm{H}^{+}, 1.1$ to 5.7 $\mathrm{mol} \cdot \mathrm{L}^{-1}$ of $\mathrm{Cl}^{-}$and $25^{\circ} \mathrm{C}( \pm 2)$.

Table 3. Separation factor of the $\mathrm{Zr} / \mathrm{Hf}$ for the acid extractants in hydrochloric medium.

\begin{tabular}{cccc}
\hline \multirow{2}{*}{$\mathrm{H}^{+}\left(\mathrm{mol}^{-1}\right)$} & \multicolumn{3}{c}{ Separation factor(SF) $\mathrm{Zr} / \mathrm{Hf}$} \\
\cline { 2 - 4 } & DEHPA & IONQUEST $^{\oplus} 801$ & CYANEX $^{\oplus} 272$ \\
\hline 1.0 & 1.2 & 1.1 & 22.9 \\
2.0 & 1.3 & 1.1 & 22.1 \\
3.0 & 1.2 & 1.2 & 23.3 \\
4.0 & 1.6 & 1.2 & 31.0 \\
5.0 & 1.2 & 1.2 & 22.0 \\
\hline
\end{tabular}




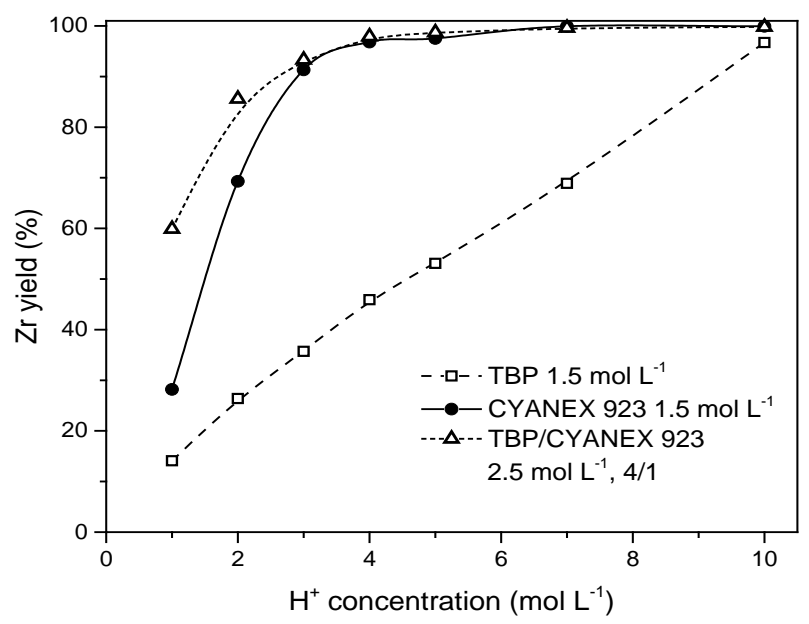

(a)

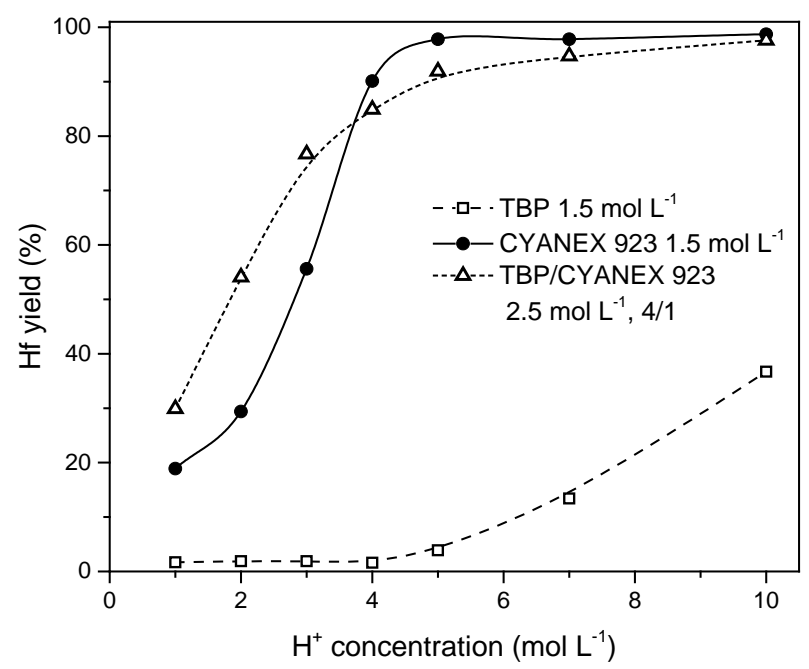

(b)

Figure 4. Efficiency in the extraction of $\mathrm{Zr}$ (a) and $\mathrm{Hf}$ (b) for the solvating extractants in nitric medium. Aqueous phase: $15.0 \mathrm{~g} \cdot \mathrm{L}^{-1}$ of $\mathrm{Zr}, 0.6 \mathrm{~g} \cdot \mathrm{L}^{-1}$ of $\mathrm{Hf}, 1.0$ to $10.0 \mathrm{~mol} \cdot \mathrm{L}^{-1}$ of $\mathrm{H}^{+}, 1.3$ to $11 \mathrm{~mol} \cdot \mathrm{L}^{-1}$ of $\mathrm{NO}_{3}{ }^{-}$and $25^{\circ} \mathrm{C}( \pm 2)$.

Table 4. Separation factor of the $\mathrm{Zr} / \mathrm{Hf}$ for solvating extractants in nitric medium.

\begin{tabular}{cccc}
\hline \multirow{2}{*}{$\mathrm{H}^{+}\left(\mathrm{mol}^{-\mathrm{L}^{-1}}\right)$} & \multicolumn{3}{c}{ Separation factor (SF) Zr/Hf } \\
\cline { 2 - 4 } & TBP & CYANEX"923 & TBP/CYANEX"923 \\
\hline 1.0 & 0.7 & 1.7 & 3.5 \\
2.0 & 1.6 & 4.4 & 13.6 \\
3.0 & 3.5 & 10 & 8.6 \\
4.0 & 4.7 & 5.9 & 8.5 \\
5.0 & 13.1 & 13.5 & 6.7 \\
7.0 & 51.3 & 25.7 & 14.6 \\
10 & 51.0 & 15.9 & 15.5 \\
\hline
\end{tabular}


CYANEX 923 presents an extraction yield over $90 \%$ for $\mathrm{Zr}$, but the selectivity is lower than that observed for TBP. For TBP the extraction percentage and the separation factor increase significantly for values greater than $7.0 \mathrm{~mol} \cdot \mathrm{L}^{-1}$ of $\mathrm{H}^{+}$.

2) Hydrochloric medium

Figure 5 shows the results of the extraction of zirconium and hafnium using the acid extractants TBP, CYANEX 923 and TBP/CYANEX 923 in a hydrochloric medium. Table 5 shows the separation factor of $\mathrm{Zr} / \mathrm{Hf}$ for the solvating extractants in this medium. When TBP was used in acidities lower than $5.0 \mathrm{~mol} \cdot \mathrm{L}^{-1}$, in a hydrochloric medium, there was no significant extraction of $\mathrm{Zr}$ and $\mathrm{Hf}$ metals. In acidities $7.0 \mathrm{~mol} \cdot \mathrm{L}^{-1}$ and 10 $\mathrm{mol} \cdot \mathrm{L}^{-1}$, the extraction of zirconium was similar to that achieved in nitric acid medium;

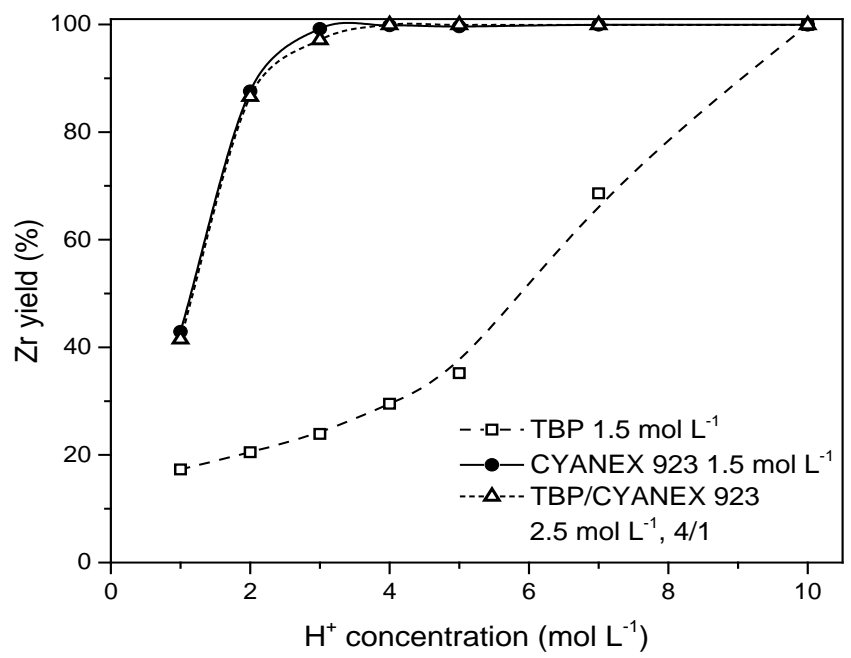

(a)

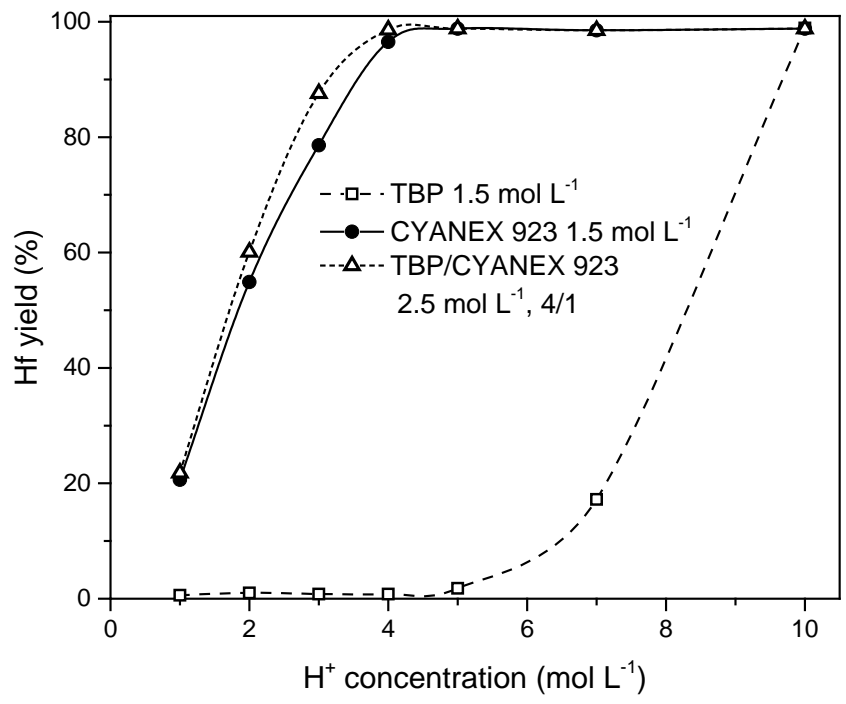

(b)

Figure 5. Efficiency in the extraction of $\mathrm{Zr}$ (a) and $\mathrm{Hf}$ (b) for the solvatingextractants in hydrochloric medium. Aqueous phase: $15.0 \mathrm{~g} \cdot \mathrm{L}^{-1}$ of $\mathrm{Zr}, 0.6 \mathrm{~g} \cdot \mathrm{L}^{-1}$ of $\mathrm{Hf}, 1.0$ to $10.0 \mathrm{~mol} \cdot \mathrm{L}^{-1}$ of $\mathrm{H}^{+}, 1.1$ to $10.8 \mathrm{~mol} \cdot \mathrm{L}^{-1}$ of $\mathrm{Cl}^{-}$and $25^{\circ} \mathrm{C}( \pm 2)$. 
Table 5. Separation factor of the $\mathrm{Zr} / \mathrm{Hf}$ for solvating extractants in hydrochloric medium.

\begin{tabular}{cccc}
\hline \multirow{2}{*}{$\mathrm{H}^{+}\left(\mathrm{mol}^{-\mathrm{L}^{-1}}\right)$} & \multicolumn{3}{c}{ Separation factor $(\mathrm{FS}) \mathrm{Zr} / \mathrm{Hf}$} \\
\cline { 2 - 4 } & TBP & CYANEX 923 & TBP/CYANEX 923 \\
\hline 1.0 & 0.3 & 2.9 & 2.5 \\
2.0 & 4.9 & 4.9 & 4.2 \\
3.0 & 4.2 & 3.2 & 5.9 \\
4.0 & 5.8 & 5.7 & 14.9 \\
5.0 & 7.0 & 25.7 & 23.0 \\
7.0 & 10.5 & 25.1 & 25.1 \\
10 & 21.4 & 31.6 & 25.7 \\
\hline
\end{tabular}

however, there was a significant increase in the extraction of $\mathrm{Hf}$, which caused a reduction in the separation factor. For the extractants CYANEX 923 and the TBP/CYANEX 923 mixture, the behavior was similar to that observed in nitric acid medium, with a gradual increase in the metals extraction until the concentration of $5.0 \mathrm{~mol} \cdot \mathrm{L}^{-1}$ of $\mathrm{H}^{+}$and keeping constant for higher acidities.

According to the results presented above, we noticed that nitric medium was the most effective in the separation of $\mathrm{Zr} / \mathrm{Hf}$ when TBP was used. Hydrochloric medium presented formation of a third phase. This makes the process impractical. However, both nitric and hydrochloric media need very high acidity in the feed solution. For the optimal result, which was obtained with TBP in nitric medium, the acidity needed was $7.0 \mathrm{~mol} \cdot \mathrm{L}^{-1}$. In hydrochloric medium, the best results were also obtained with very high acidity, more than $5.0 \mathrm{~mol} \cdot \mathrm{L}^{-1}$. It was observed that separation of zirconium and hafnium is favored by high acidities, but considering that this is a very drastic condition, it is necessary to evaluate in what way the acidity influences the $\mathrm{Zr} / \mathrm{Hf}$ separation, in other to better understand the system and to seek a way to decrease the acidity of the process. According to the results presented above, we chose to continue these studies in a nitric acid medium using TBP as extractant.

\subsection{Separation of $\mathrm{Zr} / \mathrm{Hg}$ from the Liquor Generated by the Fusion of Zircon and Liquor Generated by Hydroxides}

Figure 6 shows the extraction yields and the separation factors obtained in experiments with liquors generated from the leaching product of alkaline fusion of zircon and the solution generated from the hydroxides of $\mathrm{Zr}$ and $\mathrm{Hf}$ in nitric acid medium. In both solutions, the levels of $\mathrm{Zr}$ and $\mathrm{Hf}$ were $15 \mathrm{~g} \cdot \mathrm{L}^{-1}$ and $0.6 \mathrm{~g} \cdot \mathrm{L}^{-1}$ respectively. In these experiments the acidity varied between 1.0 and $7.0 \mathrm{~mol} \cdot \mathrm{L}^{-1} \mathrm{H}^{+}$, and $3.0 \mathrm{~mol} \cdot \mathrm{L}^{-1}$ of TBP was used as extractant.

As noted, the results obtained from the liquor prepared from the product of alkaline fusion of zircon showed much better results than those obtained from the solution prepared from dissolution of hydroxides provided by the Centro Tecnológico da Marinha (CTM)-SP (Table 6). This fact may have occurred due to the presence of sulfate in the hydroxide solution, which is absent in the liquor prepared from zircon. 


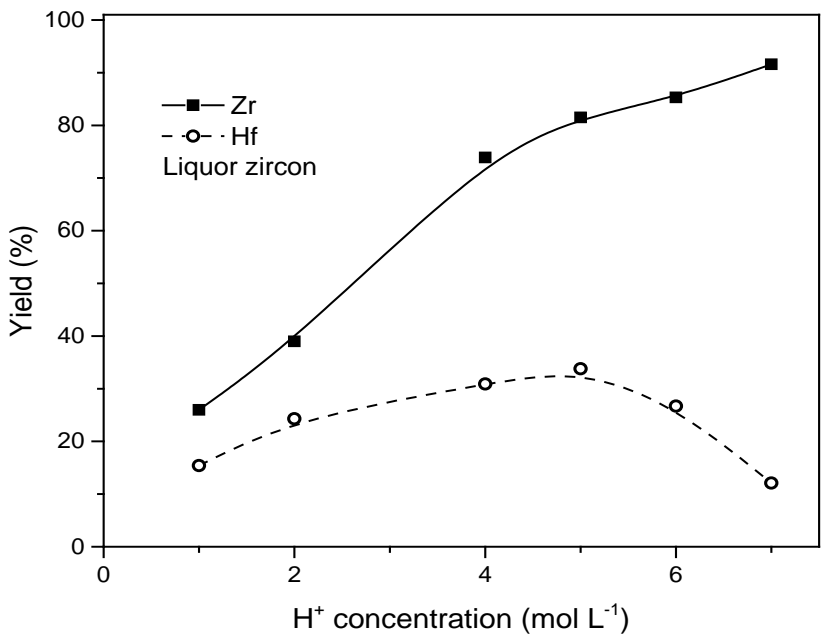

(a)

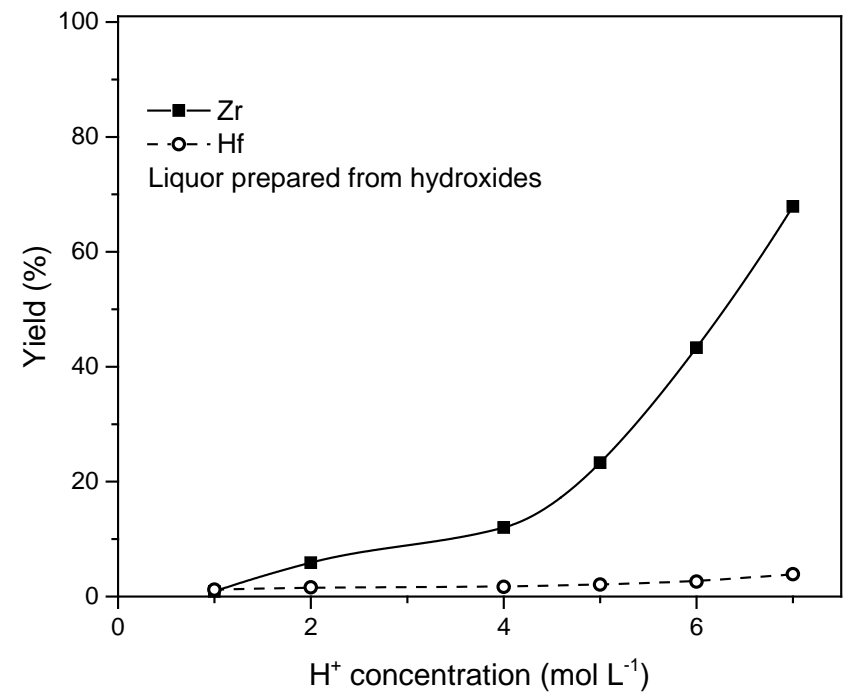

(b)

Figure 6. Efficiency in the extraction of $\mathrm{Zr}$ and $\mathrm{Hf}$ for zircon (a) and hydroxides (b) liquors. Aqueous phase: $15.0 \mathrm{~g} \cdot \mathrm{L}^{-1}$ of $\mathrm{Zr}, 0.6 \mathrm{~g} \cdot \mathrm{L}^{-1}$ of $\mathrm{Hf}, 1.0$ to $7.0 \mathrm{~mol} \cdot \mathrm{L}^{-1}$ of $\mathrm{H}^{+}$, TBP $3.0 \mathrm{~mol} \cdot \mathrm{L}^{-1}$ and $25^{\circ} \mathrm{C}$ $( \pm 2)$.

Table 6. Separation factor of the $\mathrm{Zr} / \mathrm{Hf}$ for two types of liquos in nitric acid medium.

\begin{tabular}{ccc}
\hline & \multicolumn{2}{c}{ Separation factor $(\mathrm{FS}) \mathrm{Zr} / \mathrm{Hf}$} \\
\cline { 2 - 3 } $\mathrm{H}^{+}\left(\mathrm{mol} \cdot \mathrm{L}^{-1}\right)$ & Liquor zircon & Liquor prepared from hydroxides \\
\hline 1.0 & 1.1 & 0.7 \\
2.0 & 3.5 & 1.6 \\
4.0 & 13.7 & 4.7 \\
5.0 & 11.4 & 13.1 \\
6.0 & 13.7 & 13.7 \\
7.0 & 79.3 & 51.3 \\
\hline
\end{tabular}




\section{Conclusion}

The cationic extractants investigated were not suitable for the separation of $\mathrm{Zr}$ and $\mathrm{Hf}$ metals. In nitric or hydrochloric medium, at the acidities investigated, there was a high extraction of metals by these extractants but without good selectivity. Extraction yields higher than 99\% have been observed when using DEHPA and IONQUEST 801 in both media and with acidity of $5 \mathrm{~mol} \cdot \mathrm{L}^{-1}$, but the separation factors reached around 1.0. CYANEX 272 showed separation factors ranging from 22 to 25 but with high extraction of $\mathrm{Hf}$ (greater than 95\%). Another factor to consider is the high extraction of metals in the acidity of $5 \mathrm{~mol} \cdot \mathrm{L}^{-1}$, which indicates a hard stripping of metals. For solvating extractants the best results were obtained using TBP in acidity of $7.0 \mathrm{~mol} \cdot \mathrm{L}^{-1}$ in nitric acid medium. There was no extraction of $\mathrm{Zr}$ and $\mathrm{Hf}$ when using amines as extractants in both nitric acid and hydrochloric acid media for the conditions investigated. Using the liquor generated by zircon the yield and separation factors were better than those achieved when the liquor generated from the hydroxides was used. It can be observed that both nitric and hydrochloric media need that the acidity of the feed solution be very high, the best results were obtained with very high acidity-higher than $5.0 \mathrm{~mol} \cdot \mathrm{L}^{-1}$ for nitric and hydrochloric media. It was observed that separation of zirconium and hafnium is favored by high acidities, but considering that this is a very drastic condition, it is necessary to evaluate in what way the acidity influences the $\mathrm{Zr} / \mathrm{Hf}$ separation in other to better understand the system and to seek a way to decrease the acidity of the process.

\section{Acknowledgements}

The authors would like to thank FAPEMIG, CNPq, FINEP and CAPES for financial support, and techinicians from CDTN which also contributed to the development of this work, especially Luiz C. da Silva, Walmir M. Garcia and Liliane P. Tavares.

\section{References}

[1] IAEA (2008) Thermophysical Properties of Materials for Nuclear Engineering: A Tutorial and Collection of Data, Vienna.

[2] Habashi, F. (1997) Handbook of Extractive Metallurgy. 3rd Edition, Wiley, Die Deutsche Bibliothek-CIP-Einheitsaufnahme.

[3] Choi, J.H., Mao, Y. and Chang, J.P. (2011) Development of Hafnium Based High-k Materials-A Review. Mater. Sci. Eng. R Reports, 72, 97-136.

[4] Amaral, J.C.B.S. (2015) Separação de Zircônio-háfnio para obtenção de óxido de zircõnio de grau nuclear pela técnica de extração por solventes. Centro de Desenvolvimento da Tecnologia Nuclear, CDTN-Belo Horizonte 2015.

[5] Abdel-Rehim, A.M. (2005) A New Technique for Extracting Zirconium form Egyptian Zircon Concentrate. Int. J. Miner. Process., 76, 234-243. http://dx.doi.org/10.1016/j.minpro.2005.02.004

[6] Manhique, A., Kwela, Z. and Focke, W.W. (2003) De Wet Process for the Beneficiation of Zircon: Optimization of the Alkali Fusion Step. Ind. Eng. Chem. Res., 42, 777-783. http://dx.doi.org/10.1021/ie020140c 
[7] Beyer, G.H., Spink, D.R., West, J.B. and Wilhelm, H.A. (1954) Caustic Treatment of Zircon Sand. Iowa, 1954.

[8] Reddy, B.R., Kumar, J.R., Raja, K.P. and Reddy, A.V. (2004) Solvent Extraction of Hf(IV) from Acidic Chloride Solutions Using Cyanex 302. Miner. Eng., 17, 939-942.

http://dx.doi.org/10.1016/j.mineng.2004.04.004

[9] Taghizadeh, M., Ghasemzadeh, R., Ashrafizadeh, S.N., Saberyan, K. and Ghannadi Maragheh, M. (2007) Selective Zirconium Stripping of a Loaded Cyanex 272 Using Taguchi Orthogonal Array Design. Miner. Eng., 20, 1401-1403. http://dx.doi.org/10.1016/j.mineng.2007.07.002

[10] Xu, Z.G., Wu, Y.K., Zhang, J.D., Zhang, L. and Wang, L.J. (2010) Equilibrium and Kinetic Data of Adsorption and Separation for Zirconium and Hafnium onto MIBK Extraction Resin. Trans. Nonferrous Met. Soc. China Eng.Lish Ed., 20, 1527-1533.

[11] Xu, Z.G., Wang, L.J., Wu, Y.K., Chi, R.A., Zhang, L. and Wu, M. (2012) Solvent Extraction of Hafnium from Thiocyanic Acid Medium in DIBK-TBP Mixed System. Trans. Nonferrous Met. Soc. China Eng.Lish Ed., 22, 1760-1765.

[12] Delons, L., Lagarde, S., Favre-Reguillon, A., Pellet-Rostaing, S., Lemaire, M. and Poriel, L. (2008) Process for the Separation of Hafnium and Zirconium. US Patent No. 20080031791 A1.

[13] Taghizadeh, M., Ghasemzadeh, R., Ashrafizadeh, S.N., Saberyan, K. and Maragheh, M.G. (2008) Determination of Optimum Process Conditions for the Extraction and Separation of Zirconium and Hafnium by Solvent Extraction. Hydrometallurgy, 90, 115-120. http://dx.doi.org/10.1016/j.hydromet.2007.10.002

[14] Biswas, R.K. and Hayat, M. (2002) Kinetics of Solvent Extraction of Zirconium (IV) from Chloride Medium by D2EHPA in Kerosene Using the Sing.Le Drop Technique. Hydrometallurgy, 65, 205-216. http://dx.doi.org/10.1016/S0304-386X(02)00089-0

[15] Biswas, R.K. and Hayat, M.A. (2002) Solvent Extraction of Zirconium (IV) from Chloride Media by D2EHPA in Kerosene. Hydrometallurgy, 63, 149-158. http://dx.doi.org/10.1016/S0304-386X(01)00220-1

[16] Ritcey, G.M. and Ashbrook, A.W. (1984) Solvent Extraction. 2nd Edition, Elsevier Science Publishers B. V., Amsterdam, Oxford, New York, Tokyo.

[17] Thompson, R. (1980) Speciality Inorganic Chemicals. 40th Edition, University of Salford, Salford.

[18] Zielen, A.J. and Connick, R.E. (1956) The Hydrolytic Polymerization of Zirconium in Perchloric Acid Solutions. J. Am. Chem. Soc., 78, 5785. http://dx.doi.org/10.1021/ja01603a019

[19] Sato, T. and Watanabe, H. (1970) The Extraction of Zirconium (IV) from Hydrochloric Acid Solutions by Tricaprylmethylammonium Chloride. Anal. Chim. Acta, 49, 463-471. http://dx.doi.org/10.1016/S0003-2670(00)86822-1 
Submit or recommend next manuscript to SCIRP and we will provide best service for you:

Accepting pre-submission inquiries through Email, Facebook, LinkedIn, Twitter, etc. A wide selection of journals (inclusive of 9 subjects, more than 200 journals)

Providing 24-hour high-quality service

User-friendly online submission system

Fair and swift peer-review system

Efficient typesetting and proofreading procedure

Display of the result of downloads and visits, as well as the number of cited articles

Maximum dissemination of your research work

Submit your manuscript at: http://papersubmission.scirp.org/

Orcontactwjet@scirp.org 